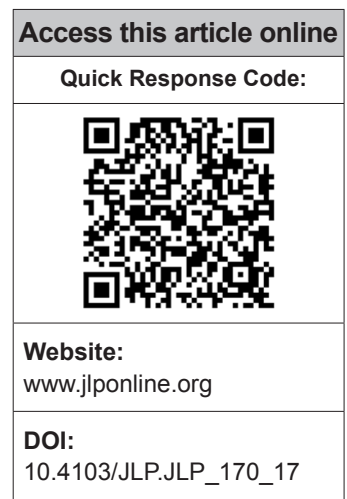

Department of Pharmacology, Toxicology and Medicine, College of Medicine, Al-Mustansiriya University, Baghdad, Iraq

Address for correspondence: Dr. Hayder M. Al-Kuraishy,

Department of

Pharmacology, Toxicology and Medicine, College of Medicine, Al-Mustansiriya University,

P. O. Box 14132, Baghdad, Iraq. E-mail: Hayderm36@ Yahoo.Com

Submission: 24-11-2017 Accepted: 31-01-2018

\title{
Rosuvastatin as forthcoming antibiotic or as adjuvant additive agent: In vitro novel antibacterial study
}

\author{
Hayder M. Al-Kuraishy, Ali I. Al-Gareeb, Ali K. Al-Buhadily
}

\section{Abstract:}

INTRODUCTION: Rosuvastatin is a lipid-lowering agent that inhibits 3-hydroxy-3-methylglutaryl coenzyme A reductase leading to a reduction of cholesterol biosynthesis. Many studies have shown an association between statins use and the reduction of sepsis. The aim of the present study was to evaluate the in vitro combined antibacterial activity of rosuvastatin and cefixime.

MATERIALS AND METHODS: Five pathogenic bacteria isolates (Gram positive and Gram negative) were used for testing the antibacterial activity of rosuvastatin alone and in combination with cefixime.

RESULTS: Rosuvastatin mainly inhibited Klebsiella pneumoniae and Escherichia coli where it caused zones of inhibition of $(17.9 \pm 0.6 \mathrm{~mm})$ and $(16.9 \pm 0.3 \mathrm{~mm})$, respectively; however, it moderately inhibited the growth of Staphylococcus epidermidis $(12.9 \pm 0.2 \mathrm{~mm})$ and Staphylococcus aureus $(12.76 \pm 0.2)$ and produced less inhibition for Pseudomonas aeruginosa growth where it led to a zone of inhibition equal to $(9.1 \pm 0.5 \mathrm{~mm})$. Minimal inhibitory concentration $(\mu \mathrm{g} / \mathrm{mL})$ of rosuvastatin was high compared to cefixime. Fractional inhibitory concentration (FIC) of rosuvastatin was low for $E$. coli and $K$. pneumoniae compared to the other types of bacterial strains. Rosuvastatin exhibited additive effects with cefixime against $E$. coli and $K$. pneumoniae. $\Sigma \mathrm{FIC}$ index was 0.536 and 0.734 for $E$. coli and $K$. pneumoniae, respectively.

CONCLUSION: Rosuvastatin has a significant antibacterial activity against both Gram-negative and Gram-positive bacteria with a potential additive effect when used in combination with cefixime.

Key words:

Antibacterial activity, cefixime, fractional inhibitory concentration, rosuvastatin

\section{Introduction}

Trang he increasing phenomenons of bacterial resistance to the antimicrobial agents are due to the improper and indiscriminate use of antimicrobial drugs, which causes drug resistance to become a global health threat. Therefore, the steady increase of bacterial resistance to existing antimicrobial agents is a serious problem; thus, there is a dire need to investigate for new classes of antibacterial agents against infectious diseases. ${ }^{[1]}$

Antibiotics exist in large number, but their uses have become limited due to the

This is an open access journal, and articles are distributed under the terms of the Creative Commons Attribution-NonCommercial-ShareAlike 4.0 License, which allows others to remix, tweak, and build upon the work non-commercially, as long as appropriate credit is given and the new creations are licensed under the identical terms.

For reprints contact: reprints@medknow.com development of drug resistance and short- or long-term toxicity. Since the development of a new antibiotic is complicated and difficult, so augmentation of the present antibiotics might be a future clarification. ${ }^{[2]}$ A number of pharmaceutical preparations and drugs that are used in the management of chronic diseases have shown some antibacterial activity; these agents called nonantibiotics. ${ }^{[3]}$ Various pharmacological classes have some antimicrobial effects on microbial metabolism; these non-antibiotic agents may have a direct antibacterial activity or augment the effect of antibiotics. Therefore, these nonantibiotics might be adequate to modify bacterial metabolism and act additively or synergistically with some antibiotics. ${ }^{[4]}$

How to cite this article: Al-Kuraishy HM, Al-Gareeb AI, Al-Buhadily AK. Rosuvastatin as forthcoming antibiotic or as adjuvant additive agent: In vitro novel antibacterial study. J Lab Physicians 2018;10:271-5. 
Rosuvastatin is a lipid-lowering agent that inhibits 3-hydroxy-3-methylglutaryl coenzyme A (HMG-CoA) reductase leading to the reduction of cholesterol biosynthesis. ${ }^{[5]}$ Paricahua et al.'s study showed an association between statins use and reduction of sepsis, as atorvastatin can reduce endothelial neutrophil adhesion and cytokine release which reduce the risk of sepsis in patients with peripheral vascular diseases. Moreover, patients on statins are less likely to develop septicemia when becoming infected. ${ }^{[6]}$ This pleiotropic effect of statins may play a role in the augmentation of specific antibiotic action. Moreover, rosuvastatin has significant antimicrobial effect by unknown mechanism. [7]

Cefixime is a bactericidal third-generation cephalosporin that inhibits bacterial cell wall synthesis through inhibition of peptidoglycan synthesis, thus it is effective for both Gram-positive and Gram-negative bacteria. Cefixime is used for the treatment of different bacterial infections such as urinary tract infection, gonorrhea, pneumonia, and Lyme disease. ${ }^{[8]}$

Drug synergism between known antibiotics and other agents is a novel concept. Therefore, the aim of the present study was to evaluate the in vitro combined antibacterial activity of rosuvastatin and cefixime.

\section{Materials and Methods}

\section{Bacterial isolates}

Five pathogenic bacterial isolates (Gram positive and Gram negative) including Escherichia coli (ATCC 25,922), Klebsiella pneumoniae (ATCC 100,31), Staphylococcus epidermidis (ATCC 12865), Pseudomonas aeruginosa (ATCC 195,82), and Staphylococcus aureus (ATCC 6538) were obtained from Bacteriology Laboratory/Department of Microbiology/College of Sciences. Bacterial strains were maintained in nutrient agar according to their growth for $24 \mathrm{~h}$ at $37^{\circ} \mathrm{C}$, and then, one colony from each stock culture was inoculated in $4 \mathrm{~mL}$ nutrient broth.

\section{Chemicals}

Rosuvastatin $20 \mathrm{mg}$ tablets/once daily (Crestor, AstraZeneca, Plankstadt, Germany) and cefixime tablets USP $400 \mathrm{mg}$ /once daily (Suprax, Lupin Pharmaceuticals, Baltimore, Maryland, USA) were purchased from a private pharmacy. Dimethyl sulfoxide (DMSO) was used as a solvent (DMSO had no antibacterial activity and regarded as a negative control).

\section{Antibacterial activity}

The antibacterial activity was evaluated by disc diffusion method that based on the spread of tested agents in a solid medium. ${ }^{[9]}$ Mueller-Hinton agar was poured in sterile petri dishes (90 $\mathrm{mm}$ diameter), and the paper discs (6 mm diameter) are impregnated with $2 \mu \mathrm{L}$ rosuvastatin, cefixime, a combination of rosuvastatin with cefixime, and DMSO as a negative control and were placed on the inculcated agar surface. Petri dishes were let to stand for $30 \mathrm{~min}$ at room temperature and then at $37^{\circ} \mathrm{C}$ before incubation for $24 \mathrm{~h}$. The antibacterial effect was reflected by the manifestation of the clear circular zone corresponding to the lack of bacterial growth.

Assessment of minimal inhibitory concentration Serial dilution method according to the National Committee for Clinical Laboratory Standard ${ }^{[10]}$ was done to obtain the stock solution of $10 \mathrm{mg}$ of rosuvastatin or $100 \mathrm{mg}$ cefixime which were dissolved in $1 \mathrm{~mL}$ DMSO, and then, serial dilutions were prepared. The serially diluted agents were added to plates containing Mueller-Hinton Gold agar and then steer replicator containing $\left(5 \times 10^{5} \mathrm{CFU} /\right.$ drop) of different bacterial strains was placed on each plate. DMSO plate was regarded as control. All plates were incubated for $18 \mathrm{~h}$ at $37^{\circ} \mathrm{C}$. Minimal inhibitory concentration (MIC) represents the lowest concentration at which no visible growth was detected. Plates were read in duplicate, and then, MICs were recorded regarding breakpoints in tables of the National Committee for Clinical and Laboratory Standards Institute to conclude resistance and susceptibility.

\section{Determination of synergy test}

Mueller-Hinton agar plates were inculcated with $0.5 \mathrm{McF}$ arland turbidity standard suspensions of each isolate, and then, the impregnated antibiotic disc alone or in combination with rosuvastatin was placed onto each plate then incubated at $35^{\circ} \mathrm{C}$ for $48 \mathrm{~h}$ for estimation of fractional inhibitory concentration (FIC) index. ${ }^{[11]}$ For testing of the combination, after application of cefixime for $1 \mathrm{~h}$, it was replaced with rosuvastatin on the same agar. FIC of cefixime $(\mathrm{A})=$ MIC of drug $\mathrm{A}$ in combination $/ \mathrm{MIC}$ of drug A, FIC of rosuvastatin (B) = MIC of drug $B$ in combination/MIC of drug B alone, then $\Sigma$ FIC index $=$ FIC of drug A + FIC of drug B. $\Sigma$ FIC index $<0.5$ indicated synergy, between 0.5 and 1.0 indicated additive effect, between 1.0 and $<4.0$ indicated indifference, and above 4.0 indicated antagonism. ${ }^{[12]}$

\section{Results}

The present study demonstrated a significant antibacterial activity of rosuvastatin against specific bacterial strains. In vitro effect of rosuvastatin led to inhibition of bacterial growth that was reflected by the diameter of the zone of inhibition. It mainly inhibited K. pneumoniae and E. coli where it causes zone of inhibition of $(17.9 \pm 0.6 \mathrm{~mm})$ and $(16.9 \pm 0.3 \mathrm{~mm})$, respectively. Rosuvastatin moderately inhibited the growth of S. epidermidis $(12.9 \pm 0.2 \mathrm{~mm})$ and S. aureus $(12.76 \pm 0.2)$, but it produced less inhibition for 
$P$. aeruginosa where it led to a zone of inhibition equal to $(9.1 \pm 0.5 \mathrm{~mm})$. Cefixime produced a large zone of inhibition for all of the selected bacterial strains except for $P$. aeruginosa. Combined cefixime and rosuvastatin led to a more significant antibacterial effect than cefixime and rosuvastatin $(P<0.01)$ for all selected bacterial strains [Table 1].

MIC in $\mu \mathrm{g} / \mathrm{mL}$ of rosuvastatin was high compared to cefixime mainly for E. coli and K. pneumoniae $(P<0.01)$. MIC of cefixime was high for $P$. aeruginosa and $S$. aureus and comparatively low for E. coli and K. pneumoniae. Combination of rosuvastatin and cefixime led to better MIC values primarily against E. coli, K. pneumoniae and less for other types of bacterial strains compared to cefixime alone [Table 2].

FIC of rosuvastatin was low for E. coli and K. pneumoniae compared to the other type of bacterial strains. Rosuvastatin exhibited additive effect with cefixime against E. coli and K. pneumoniae. $\Sigma$ FIC index was 0.536 and 0.734 , respectively, for E. coli and K. pneumoniae since $\Sigma$ FIC was between 0.5 and 1.0. Indifference effects were observed for other investigated bacterial strains since ¿FIC was between 1.0 and 4.0 [Table 3].

\section{Discussion}

With the raise in the frequency of resistance to antibiotics, alternative agents could be of interest. Some of the nonantibiotic agents are known to have antibacterial effects, which could be of vast magnitude in the treatment of bacterial infections. Various drugs have been estimated not only for direct antibacterial effect but also as resistance-modifying agents through modulation of antibiotic activity or overturning of bacterial resistance. ${ }^{[13-15]}$

The present study illustrated significant in vitro antibacterial effects of rosuvastatin mainly against $E$. coli and K. pneumoniae, as confirmed by Coban et al.'s study that confirmed the antibacterial activity of statins. ${ }^{[16]}$

The unexpected antibacterial activity of statins was initially observed by Jerwood and Cohen's 2008 study that demonstrated significant antibacterial activity of simvastatin and to a lesser extent fluvastatin against methicillin-resistant S. aureus (MRSA) aureus and methicillin-sensitive S. aureus (MSSA). ${ }^{[17]}$

On the other hand, Graziano et al. exemplified that only simvastatin has antibacterial activity against MRSA and MSSA biofilm formation and growth viability. ${ }^{[18]}$

Furthermore, many studies showed a significant antibacterial activity of rosuvastatin ${ }^{[19,20]}$ that correspond with findings of the present study.
Table 1: Zone of inhibition $(\mathrm{mm})$ of cefixime and rosuvastatin

\begin{tabular}{lcccc}
\hline Bacterial isolates & Cefixime & Rosuvastatin & Combination & $P$ \\
\hline $\begin{array}{l}\text { Escherichia coli } \\
\begin{array}{l}\text { Klebsiella } \\
\text { pneumoniae }\end{array}\end{array}$ & $19.8 \pm 0.5^{\S}$ & $16.9 \pm 0.3^{\S}$ & $20.7 \pm 0.9^{\#, \S}$ & $0.002^{*}$ \\
$\begin{array}{l}\text { Staphylococcus } \\
\text { epidermidis }\end{array}$ & $12.9 \pm 0.6^{\S}$ & $17.9 \pm 0.6^{\S}$ & $21.9 \pm 0.6^{\#, \S}$ & $0.001^{*}$ \\
$\begin{array}{l}\text { Pseudomonas } \\
\text { aeruginosa }\end{array}$ & $6.3 \pm 0.1^{\S}$ & $9.1 \pm 0.5^{\S}$ & $15.9 \pm 0.8^{\#, \S}$ & $0.0001^{*}$ \\
$\begin{array}{l}\text { Staphylococcus } \\
\text { aureus }\end{array}$ & $11.8 \pm 0.4^{\S}$ & $12.76 \pm 0.2^{\S}$ & $16.5 \pm 0.6^{\#, \S}$ & $0.0001^{*}$ \\
\hline
\end{tabular}

${ }^{*} P<0.01$, Tukey HSD post hoc test, ${ }^{\#} P<0.01$ (combination vs. rosuvastatin), Tukey HSD post hoc test, ${ }^{\S} P<0.0001$ compared to the DMSO (negative control). Results are expressed as mean \pm SE. SE = Standard deviation, DMSO = Dimethyl sulfoxide, HSD = Honestly significant difference

Table 2: Minimal inhibitory concentration $(\mu \mathrm{g} / \mathrm{mL})$ of cefixime and/or rosuvastatin

\begin{tabular}{|c|c|c|c|c|}
\hline $\begin{array}{l}\text { Bacterial } \\
\text { isolates }\end{array}$ & Cefixime & Rosuvastatin & Combination & $P$ \\
\hline Escherichia coli & $1.3 \pm 0.89^{\S}$ & $102.88 \pm 4.93^{\S}$ & $0.7 \pm 0.2^{\S}$ & $0.0000^{*}$ \\
\hline $\begin{array}{l}\text { Klebsiella } \\
\text { pneumoniae }\end{array}$ & $1.2 \pm 0.67^{\S}$ & $199.82 \pm 3.82^{\S}$ & $0.88 \pm 0.3^{\S}$ & $0.0000^{*}$ \\
\hline $\begin{array}{l}\text { Staphylococcus } \\
\text { epidermidis }\end{array}$ & $66.42 \pm 4.97 \S$ & $201.97 \pm 8.49$ & $64.83 \pm 4.96^{\#, \S}$ & $0.0000^{*}$ \\
\hline $\begin{array}{l}\text { Pseudomonas } \\
\text { aeruginosa }\end{array}$ & $60.45 \pm 4.93^{\S}$ & $278.78 \pm 8.99$ & $60.75 \pm 3.81^{\#, \S}$ & $0.0000^{*}$ \\
\hline $\begin{array}{l}\text { Staphylococcus } \\
\text { aureus }\end{array}$ & $40.64 \pm 3.62^{\S}$ & $286.12 \pm 7.93$ & $41.55 \pm 6.93^{\#, \S}$ & $0.0000^{*}$ \\
\hline
\end{tabular}

Table 3: Fractional inhibitory concentration of cefixime and/or rosuvastatin

\begin{tabular}{lcccl}
\hline $\begin{array}{l}\text { Bacterial } \\
\text { isolates }\end{array}$ & \multicolumn{2}{l}{ Cefixime Rosuvastatin } & $\begin{array}{l}\sum \text { FIC } \\
\text { index }\end{array}$ & Interpretation \\
\hline $\begin{array}{l}\text { Escherichia coli } \\
\text { Klebsiella } \\
\text { pneumoniae }\end{array}$ & 0.53 & 0.006 & 0.536 & Additive effect \\
$\begin{array}{l}\text { Staphylococcus } \\
\text { epidermidis }\end{array}$ & 0.97 & 0.004 & 0.734 & Additive effect \\
$\begin{array}{l}\text { Pseudomonas } \\
\text { aeruginosa }\end{array}$ & 1.0 & 0.21 & 1.21 & Indifference effect \\
$\begin{array}{l}\text { Staphylococcus } \\
\text { aureus }\end{array}$ & 1.02 & 0.14 & 1.16 & Indifference effect \\
\hline
\end{tabular}

FIC = Fractional inhibitory concentration

Moreover, the present study demonstrated a significant additive effect of rosuvastatin with cefixime against $E$. coli and $K$. pneumoniae, and indifferent effect against other tested bacterial isolates. It has been theorized that the combination of statins and antibiotics may augment the efficacy of the antibiotic; however, information on the synergistic or additive effect of statins with antibiotics is inadequate and contradictory. Bergman et al.'s study confirmed the synergistic activity of simvastatin but not fluvastatin or pravastatin with penicillin against S. pneumoniae and Moraxella catarrhalis. ${ }^{[21]}$ In addition, 
many studies demonstrated the augmentation of antibiotics effect by statins. ${ }^{[22,23]}$ Thus, no previous study investigated the antibacterial activity of rosuvastatin in combination with cefixime.

The mechanism of antibacterial activity of statins is uncertain, but it may be through inhibition of mevalonate pathway which is present in both human and Gram-positive bacteria for the synthesis of isoprenoid while Gram-negative bacteria use independent mevalonate pathway for isoprenoid biosynthesis which might explain the sensitivity of Gram-positive bacteria but not Gram-negative bacteria toward statins. ${ }^{[2]}$ However, in the present study, rosuvastatin mainly inhibited E. coli and K. pneumoniae regardless of the Gram type as documented by Haeri et al.'s study. ${ }^{[25]}$ Besides, lovastatin did not have any antibacterial activity even on Gram-positive bacteria in spite of potent inhibition of mevalonate pathway; thus, this mechanism is not the main mechanism. ${ }^{[26]}$

Moreover, statins attenuate bacterial virulence and production of pro-inflammatory mediators in infected macrophage during acute bacterial infection which minimizes the infection rate, ${ }^{[27]}$ but in the current study, inflammatory markers were not evaluated.

Rosuvastatin is the synthetic hydrophilic HMG-CoA reductase inhibitor and has a structural similarity with most of the synthetic statins, but unlike other statins, it contains sulfonyl functional group. ${ }^{[28]}$ This hydrophilic property may limit the penetration of bacterial cell wall mainly in $P$. aeruginosa which might explain the low antibacterial activity of rosuvastatin against $P$. aeruginosa. ${ }^{[29]}$ In addition, sulfonyl functional group in rosuvastatin may be responsible for the antibacterial effect, since synthetic acylsulfonamides have significant and potent in vitro antibacterial effects. ${ }^{[30]}$

Further probable mechanism of statins could be due to the inhibition of bacterial biofilm formation through inhibition of bacterial polysaccharide production which is essential for bacterial viability. ${ }^{[31]}$

Moreover, quorum sensing (QS) is a vital intercellular communication system in bacteria that play an important role in bacterial pathogenesis. ${ }^{[32]}$ QS molecule called as acyl-homoserine (AHL) and acts as an agonist for bacterial growth. Rosuvastatin has structural similarity with AHL, thus it interferes with QS system and bacterial motility. ${ }^{[33]}$

Herein, further studies are necessary and warranted to illustrate the main mechanism of antibacterial activity of rosuvastatin to ensure safety and efficacy when combined with a specific antibiotic.

\section{Conclusion}

Rosuvastatin has significant antibacterial activity against both Gram-negative and Gram-positive bacteria with a potential additive effect when used in combination with cefixime.

\section{Acknowledgments}

We would like to acknowledge Dr. Salah Al-windy for his great supports.

\section{Financial support and sponsorship \\ Nil.}

\section{Conflicts of interest}

There are no conflicts of interest.

\section{References}

1. Szekeres E, Baricz A, Chiriac CM, Farkas A, Opris O, Soran ML, et al. Abundance of antibiotics, antibiotic resistance genes and bacterial community composition in wastewater effluents from different Romanian hospitals. Environ Pollut 2017;225:304-15.

2. Khoshnood S, Heidary M, Mirnejad R, Bahramian A, Sedighi M, Mirzaei $\mathrm{H}$, et al. Drug-resistant gram-negative uropathogens: A review. Biomed Pharmacother 2017;94:982-94.

3. Kristiansen JE, Thomsen VF, Martins A, Viveiros M, Amaral L. Non-antibiotics reverse resistance of bacteria to antibiotics. In Vivo 2010;24:751-4.

4. Martins M, Dastidar SG, Fanning S, Kristiansen JE, Molnar J, Pagès JM, et al. Potential role of non-antibiotics (helper compounds) in the treatment of multidrug-resistant gram-negative infections: Mechanisms for their direct and indirect activities. Int J Antimicrob Agents 2008;31:198-208.

5. Al-Kuraishy HM, Al-Gareeb AI. Effects of Rosuvastatin alone or in combination with omega-3 fatty acid on adiponectin levels and cardio metabolic profile. J Basic Clin Pharm 2016;8:8-14.

6. Paricahua LI, Goncalves AFO, Pacheco SODS, Pacheco FJ. Sepsis mortality in critical care and prior statin therapy: A Retrospective cohort study in central Argentina. J Clin Diagn Res 2017;11:OC17-21.

7. Masadeh M, Mhaidat N, Alzoubi K, Al-Azzam S, Alnasser Z. Antibacterial activity of statins: A comparative study of atorvastatin, simvastatin, and rosuvastatin. Ann Clin Microbiol Antimicrob 2012;11:13.

8. Sirisolla J, Ramanamurthy KV. Formulation and evaluation of cefixime trihydrate matrix tablets using HPMC, sodium CMC, ethyl cellulose. Indian J Pharm Sci 2015;77:321-7.

9. Shokouhi S, Darazam IA, Zamanian MH. Community-acquired methicillin-resistant Staphylococcus aureus carriage rate and antimicrobial susceptibility in a tertiary center, Iran. J Res Med Sci 2017;22:71.

10. Smaill F. Antibiotic susceptibility and resistance testing: An overview. Can J Gastroenterol 2000;14:871-5.

11. Wei WJ, Yang HF. Synergy against extensively drug-resistant Acinetobacter baumannii in vitro by two old antibiotics: Colistin and chloramphenicol. Int J Antimicrob Agents 2017;49:321-6.

12. Fratini F, Mancini S, Turchi B, Friscia E, Pistelli L, Giusti G, et al. A novel interpretation of the fractional inhibitory concentration index: The case Origanum vulgare L. And Leptospermum scoparium J. R. et G. Forst essential oils against Staphylococcus aureus strains. Microbiol Res 2017;195:11-7.

13. Brooks BD, Brooks AE. Therapeutic strategies to combat antibiotic 
resistance. Adv Drug Deliv Rev 2014;78:14-27.

14. Pereira NL, Aquino PE, Júnior JG, Cristo JS, Vieira Filho MA, Moura FF, et al. Antibacterial activity and antibiotic modulating potential of the essential oil obtained from Eugenia jambolana in association with led lights. J Photochem Photobiol B 2017;174:144-9.

15. Al-Kuraishy HM, Al-Gareeb AI. Experimental antibacterial activity of selective cyclooxygenase antagonist. Int J Basic Clin Pharmacol 2013;2:381-5.

16. Coban AY, Tekeli HO, Güney AK, Durupinar B. Investigation of the in vitro antibacterial effects of statins. Mikrobiyol Bul 2010;44:161-3.

17. Jerwood S, Cohen J. Unexpected antimicrobial effect of statins. J Antimicrob Chemother 2008;61:362-4.

18. Graziano TS, Cuzzullin MC, Franco GC, Schwartz-Filho HO, de Andrade ED, Groppo FC, et al. Statins and antimicrobial effects: Simvastatin as a potential drug against Staphylococcus aureus biofilm. PLoS One 2015;10:e0128098.

19. Welsh AM, Kruger P, Faoagali J. Antimicrobial action of atorvastatin and rosuvastatin. Pathology 2009;41:689-91.

20. Alagić-Džambić L, Omerović S, Džambić M. Antimicrobial activity of rosuvastatin. Int J Pharm Technol 2015;6:7587-92.

21. Bergman P, Linde C, Pütsep K, Pohanka A, Normark S, Henriques-Normark B, et al. Studies on the antibacterial effects of statins - In vitro and in vivo. PLoS One 2011;6:e24394.

22. Lobato LS, Rosa PS, Ferreira Jda S, Neumann AdaS, da Silva MG, do Nascimento DC, et al. Statins increase rifampin mycobactericidal effect. Antimicrob Agents Chemother 2014;58:5766-74.

23. Skerry C, Pinn ML, Bruiners N, Pine R, Gennaro ML, Karakousis PC, et al. Simvastatin increases the in vivo activity of the first-line tuberculosis regimen. J Antimicrob Chemother 2014;69:2453-7.

24. Eisenreich W, Bacher A, Arigoni D, Rohdich F. Biosynthesis of isoprenoids via the non-mevalonate pathway. Cell Mol Life Sci 2004;61:1401-26.

25. Haeri MR, White K, Qharebeglou M, Ansar MM. Cholesterol suppresses antimicrobial effect of statins. Iran J Basic Med Sci 2015;18:1253-6.

26. Biradar YS, Jagatap S, Khandelwal KR, Singhania SS. Exploring of antimicrobial activity of Triphala Mashi-an ayurvedic formulation. Evid Based Complement Alternat Med 2008;5:107-13.

27. Kothe H, Dalhoff K, Rupp J, Müller A, Kreuzer J, Maass M, et al. Hydroxymethylglutaryl coenzyme A reductase inhibitors modify the inflammatory response of human macrophages and endothelial cells infected with Chlamydia pneumoniae. Circulation 2000;101:1760-3.

28. Gabr MM, Mortada SM, Sallam MA. Hexagonal liquid crystalline nanodispersions proven superiority for enhanced oral delivery of rosuvastatin: In vitro characterization and in vivo pharmacokinetic study. J Pharm Sci 2017;106:3103-12.

29. Farmer AR, Murray CK, Mende K, Akers KS, Zera WC, Beckius ML, et al. Effect of HMG-coA reductase inhibitors on antimicrobial susceptibilities for gram-negative rods. J Basic Microbiol 2013;53:336-9.

30. Berredjem M, Bouchareb F, Kaki SA, Dekhil M, Aouf NE. Synthesis and antibacterial activity of novel N-acylsulfonamides. Arabian J Chem 2017;10:S1095-9.

31. Renner LD, Weibel DB. Physicochemical regulation of biofilm formation. MRS Bull 2011;36:347-55.

32. Wang D, Shi J, Xiong Y, Hu J, Lin Z, Qiu Y, et al. A QSAR-based mechanistic study on the combined toxicity of antibiotics and quorum sensing inhibitors against Escherichia coli. J Hazard Mater 2018;341:438-47.

33. Hennessy E, Adams C, Reen FJ, O'Gara F. Is there potential for repurposing statins as novel antimicrobials? Antimicrob Agents Chemother 2016;60:5111-21. 